\title{
Química de Polímeros
}

\author{
Coordenação de J. S. Seixas de Melo, M. João Moreno, H.D. Burrows e M. Helena \\ Gil, Imprensa da Universidade, Coimbra, 2004. xii + 665 páginas. Preço: $22 €$. \\ ISBN 972-8704-22-4
}

MÁRIO N. B ER B ERAN E S A N T O S *

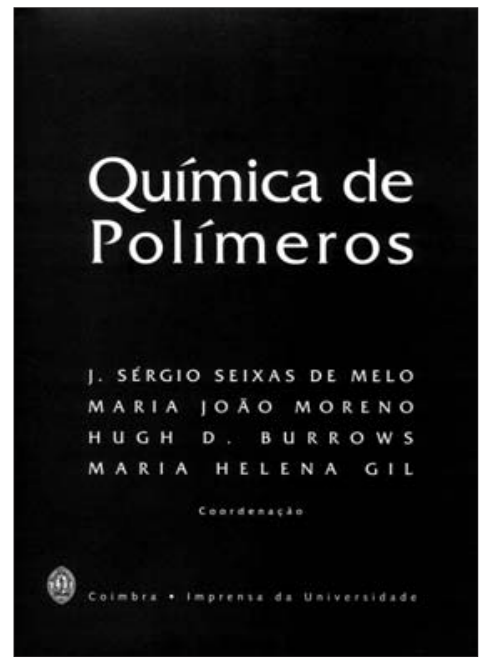

Lançado durante o XIX Encontro Nacional da Sociedade Portuguesa de Química, realizado em Coimbra, e cuja temática principal foram os polímeros, o livro Química de Polímeros reúne 22 capítulos assinados por mais de meia centena de docentes e investigadores universitários nacionais ou em colaboração com nacionais.

É aqui oportuno recordar dois factos relacionados: a criação em 2004 do Grupo de Colóides, Polímeros e Interfaces no âmbito da $S P Q$, e cujo presidente, H. D. Burrows, é um dos editores (e autores) do presente livro; e o facto de o Boletim da SPQ ter dedicado em tempos um número aos Polímeros ( $n .^{\circ} 24$, no longínquo ano de 1986 mas já mencionando os "novos" polímeros condutores), com um artigo muito semelhante (artigo Poliuretanos, Cap. II.2 do livro) e outros complementares dos capítulos do livro.

Para além de uma introdução sucinta, em que os coordenadores situam a temática dos polímeros no contexto da in- vestigação, indústria e ensino portugueses, a obra encontra-se organizada em quatro grandes secções: Síntese e processamento (5 capítulos), Estrutura e dinâmica (8 capítulos), Polímeros condutores (4 capítulos), e Biopolímeros e Biomateriais (5 capítulos).

Inserido na Série Ensino, não se trata no entanto de um manual universitário de Química de Polímeros. Como acontece com todos os livros que reúnem capítulos escritos por vários autores, não há um encadeamento perfeito, nem um tratamento sistemático de tópicos relevantes. Não há também, neste caso, uma preocupação pedagógica uniforme. Alguns autores descrevem sobretudo a sua investigação ou área de trabalho, pressupondo conhecimentos prévios ou interesse por certos pormenores que muitos leitores não terão. O livro é contudo útil para o ensino da Química de Polímeros, pois há uma maioria de capítulos em que se introduz o respectivo assunto de forma clara e bastante completa.

Declara-se no Prefácio que o objectivo primeiro do livro é fornecer uma panorâmica da actividade de investigação nacional em Química de Polímeros, com excepção da química coloidal e das macromoléculas biológicas (por exemplo proteínas). Este objectivo é plenamente atingido, e permite-nos ajuizar da actividade realizada em cada uma das áreas, nomeadamente por análise da respectiva bibliografia. 0 método de selecção de autores utilizado numa primeira fase pelos editores, baseado na Web of Knowledge (ISI) (mínimo de 10 artigos e 50 citações), é louvável. Há, ao que parece, quem afirme que o acesso nacional a esta base de dados é desnecessário, e que se trata de um desperdício de dinheiro. Trata-se de uma afirmação deplorável, mas provavelmente cada vez menos ouvida. O que não quer dizer que, em círculos restritos, não haja quem continue a fugir dos indicadores bibliométricos como o diabo foge da cruz.

Outra virtude do livro Química de Polímeros é o contributo dado para a fixação em português da respectiva terminologia.

Uma pequena achega: afirma-se na Introdução, remetendo para um endereço de internet aparentemente entretanto modificado, que o fabrico de papel em Portugal tem mais de 300 anos. De facto, o registo mais antigo conhecido (Matos Sequeira, A Abelheira e o fabrico de papel em Portugal, 1935) é de 1411, e refere-se a moínhos de água para o fabrico de papel a partir de trapos, situados em Leiria, junto ao rio Liz. Fabricase portanto papel em Portugal há (pelo menos) quase 600 anos. Mas só em meados do séc. XIX se começou a produzir na Europa o "papel de madeira", a que se refere o Cap. V.1. O inadequado tratamento químico de então levou ao papel ácido (veja-se, por exemplo, H. A. Carter, J. Chem. Educ. 74 (1997) 508) amarelado e manchado de muitos livros de oitocentos, por vezes com um cheiro desagradável, e tão frágil e feio ao pé do seu antecessor de linho ou algodão, que encontramos em perfeito estado nos livros dos séculos XVI a XIX (1. ${ }^{\text {a }}$ metade).

Química de Polímeros é, em suma, uma obra de consulta bem organizada e bem editada, que vem enriquecer a escassa bibliografia científica em português, e cuja aquisição se aconselha. 